\title{
Rejsebeskrivelsers grænseløse nytteværdi
}

af Michael Harbsmeier

Der fortælles mange historier om Immanuel Kant. En af dem går ud på, at han en dag blev spurgt af en ivrig studerende, som havde store vanskeligheder med at forene teologien med filosofien, hvad han skulle læse. Kant: "Læs rejsebeskrivelser!" Eleven insisterede, at der i dogmatikken var ting, han ikke kunne forstå. Men Kant var ubøjelig: "Læs rejsebeskrivelser!" gentog han endnu en gang.

Historien melder intet om hvorvidt hin stakkels student endte med at følge filosoffens råd. Og om det skulle have hjulpet. At læsningen af rejsebeskrivelser til gengæld kan tjene nok så mange formål havde den notorisk bofaste Königsbergborger uomtvisteligt ret i. ${ }^{1}$

At læse tekster af og om Jens Munk eller Knud Rasmussen, Vitus Bering eller Carsten Niebuhr, H. C. Andersen eller Jens Baggesen, eller for den sags skyld Hakon Mielche og Jørgen Bitsch for nu at nøjes med de mest kendte og berømte danske rejsende, at finde frem til og studere folk af samme herkomst som én selv men med en større horisont, at opspore og følge mennesker fra ens eget verdensdel eller land eller by eller egn, som ved at have været viden om har markeret stedet hvorfra de tog afsted og som de kom hjem til som havende en særlig betydning i forhold til resten af verden, er for det første et velegnet middel til bekæmpelsen af rodløshed. Der er selvfølgelig uendelig mange andre, lokale ting og sager, der kan bruges til at markere samhørighed i forhold til resten af verden, men fortidens rejsende har den unægtelige fordel samtidig ikke at fornægte og fortie, men tværtom at knytte an til den for os såvel som dem fremmede og anderledes, fjerne og hinsides omverden. 
Man kan for det andet gå et skridt videre endnu ved at glæde sig over det almengyldige og eksemplariske ved mange af fortidens rejsende og rejseforfattere som foregangsmænd. Jens Munk og Knud Rasmussen, Vitus Bering og Carsten Niebuhr, H.C. Andersen og Jens Baggesen er jo ikke berømte på grund af deres herkomst, men snarere fordi de har udvist almengyldig heltemod og udholdenhed og demonstreret betydelige videnskabelige og/eller litterære evner med deres landvindinger i ordets bogstavelige og/eller overførte betydning. Ved siden af den traditionelle eller antikvariske stolthed over at dele herkomst med de gamle rejsende findes der således en monumentalisk eller eksemplarisk beundring for dem som forbilleder vi burde efterligne.

Mindre opbyggeligt er det for det tredje, at vi også omvendt kan have overordentlig gode grunde til at kritisere og beklage, hvor fordomsfuld og snæversynet, hvor indskrænket og ideologisk, hvor etnocentrisk og racistisk vore forfædre har været (og visse medborgere stadig er) når det gjaldt (og gælder) "deandre": de fremmedei form af "hedningene", "mohammedanerne" og "de vantro", "barbarerne", "negrene" og "de vilde", eller bare "bønderne" eller"almuen" ude såvel som derhjemme. I filosofiske traktater eller teologiske pamfletter, i politiske taler, forfatninger og menneskerettighedserklæringer, i historiske fremstillinger og videnskabelige, etnografiske tekster kan der selvfølgelig også spores noget tilsvarende. Men i rejseberetningerne tages bladet ofte mere fra munden end ellers - hvorfor den slags tekster også er så velegnet som genstand for alskens kritiske opgør.

Ud fra en mere overlegen og distanceret akademisk position er det for det fjerde muligt at indtage en mere balancerende og analyserende, en historistisk og genetisk attitude: når sol og vind skal fordeles lige gælder det om at anerkende de rejsendes relative fortjenester målt i forhold til deres forgængere og efterkommere, at vurdere deres indsats ud fra deres egne og deres samtids begrænsninger, muligheder og forudsætninger. Denne fjerde og sidste, denne "historisk-videnskabelige" omgang med fortiden, som Friedrich Nietzsche har kaldt den i det essay om historiens nytteværdi, som jeg her i det hele taget støtter mig på, har unægtelig den fordel at være væsentlig mere saglig og ædruelig end de foregående, som den til gengæld - og det var hvad Friedrich Nietzsche ville advare mod - truer med at overfløddiggøre og borteliminere. 


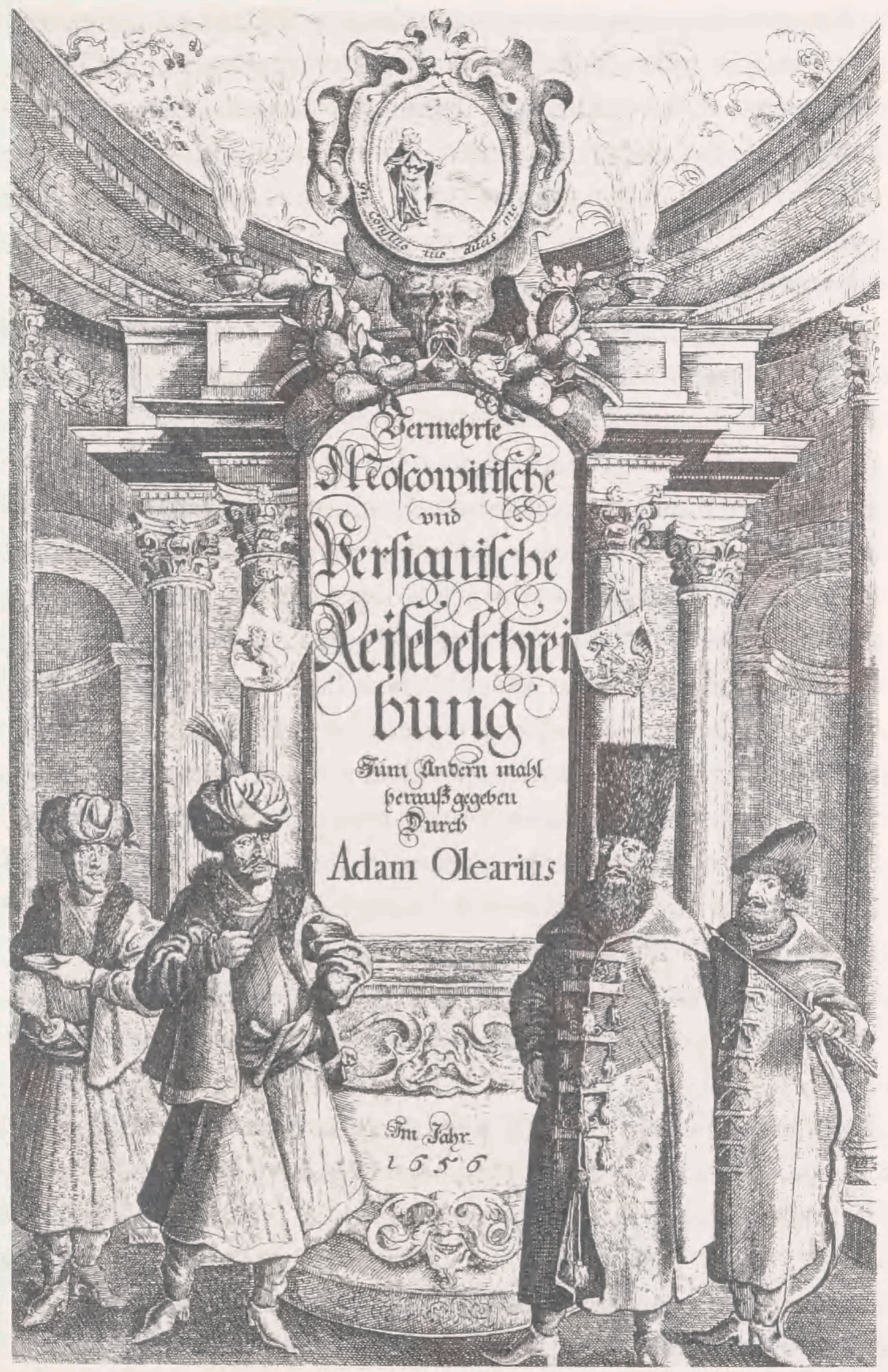

Adam Olearius foretog i 1630'erne rejser til Moskva for at få tilladelse til handel mellem Gottorp og Persien. Hovedudbyttet blev imidlertid hverken økonomisk eller politisk, men den store Offt begehrte Beschreibung der Newe Orientalischen Reise, 1647. Den vidner om hans fremragende iagttagelsesevne over for etnografiske, historiske og arkæologiske foreteelser. Her titelbladet til 2. oplag fra 1656. 
Trangen til at censurere og kontrollere, overvåge og kanalisere, kritisere og omtolke rejsende folks viden og informationer, fortællinger og beretninger har hos magthavere og meningsdannere alle dage været ganske ubændigt. Ofte har man blot beskyldt dem for at overdrive og lyve som da Herodot berettede om barbarernes skikke, men allerede Plato for eksempel ville gerne have sat overvågningen i system. I hans idealstat havde kun mænd over 50 lov til at rejse, og de var forpligtet til højtideligt at gøre rede for deres oplevelser for republikkens magtfulde råd ved hjemkomsten. Hvis de derimod på egen hånd skulle prøve at indføre fremmede og barbariske skikke og luner risikerede de dødsstraf og offentlig henrettelse.

Det er derfor ikke så mærkeligt, at kun så uendelig få af de formentlig uendelig mange mundtlige rejseberetninger gennem tiderne nåede at blive skrevet ned og dermed bevaret for eftertiden. I middelalderen for eksempel, hvor - og det ved vi fra andre kilder-folk rejste endda overordentlig meget, har det bortset fra en håndfuld til gengæld ganske berømte "opdagelsesrejsende" kun været pilgrimme til det Hellige Land der har turdet nedfælde deres fortællinger på skrift. Gennem det 16. og 17. århundrede, de store opdagelsesrejsers tidsalder, er der selvfølgelig blevet trykt utallige beretninger om de nye verdener hinsides havene, men selvom mobiliteten på tværs af alle grænser indenfor Europa formentlig har været langt større i disse århundreder end i middelalderen, er der blevet udgivet flere rejseførere og traktakter om hvordan man burde rejse og føre dagbog om sin rejse (de såkaldte apodemiske tekster) end egentlige rejseberetninger.

Først fra og med oplysningstiden er det blevet mere eller mindre almindeligt ikke blot at føre dagbog, men også at udgive en beretning om rejser, der hverken førte til det Hellige Land eller en anden hinsides verden, men blot gjaldt andre lande i Europa eller måske endda ens eget land. Men da det først var gået op for disse første "borgerlige" rejsende, at de kunne tage deres egen verden i besiddelse ved som rejsende at beskrive og analysere, debattere og kritisere forholdene hos både dem selv og hos andre, gik det gengæld overordentlig stærkt: antallet af trykte bøger nåede i anden halvdel af det 18. århundrede hidtil uanede højder, og rejseberetningernes, rejsebrevenes og rejseromanerns andel i denne enorme vækst har været endnu mere astronomisk, således at der snart ikke fandtes den plet på det europæiske landkort (eller for den sags skyld i resten af den dengang kendte 
og tilgængelige verden), der ikke var blevet "opdaget" og skildret af indtil flere forskellige borgerlige eller adelige, reformivrige eller bagstræberiske, rationalistiske eller romantiske, statistisk-videnskabelige eller poetisk-litterære, encyklopædisk registrerende eller sentimentalt indfølende rejse-forfattere.

Men som i så mange andre brancher rummede også dette imponerende boom kimen til en efterfølgende krise med strukturelle konsekvenser. Indtil slutningen af det 18 . århundrede blev de fleste rejseforfattere opfattet som øjenvidner: de blev enten anerkendt som autoriteter fordi de jo selv havde set det hele med deres egne øjne, eller også blev de beskyldt for at overdrive og lyve fordi de netop ikke havde set det de påstod. Genrens enorme vækst og popularitet ligesåvel som den omstændighed, at stadig flere beretninger handlede om steder tættere på, førte gennem de sidsteårtier af det 18. århundrede til, at det gik op for de fleste, at det ikke bare er selve virkeligheden der kan ses, men at det sete tværtimod i høj grad afhænger af øjnene der ser (og pennen der skriver). At det med andre ord er den rejsende selv og hans briller, hans fordomme og interesser, hans forudsætninger og kvalifikationer, hans opmærksomhed eller mangel på samme, der afgør hvad han har set og dermed er i stand til at fortælle. En indsigt der jo indfandt sig ganske naturligt, da så mange rejsende blev ved med at skrive om de samme velkendte steder. Men en indsigt altså, der også førte til at den "historisk-videnskabelige", den ideologikritiske og i almindelighed skeptisk-distancerede måde at læse rejsebeskrivelser på kunne vinde så megen gehør fra og med begyndelsen af det 19. århundrede og i det vi derfor kunne kalde historismens tidsalder.

At denne indsigt også indfandt hos mange af de rejsende selv fremgår af genrens differentiering: fra begyndelsen af det 19. århundrede kunne man ikke længere bare skrive en beretning om det man havde oplevet. Nej, fra nu af skulle man vælge mellem enten at være forfatter til et stykke "litteratur", eller forsker og ophavsmand til en videnskabelig rapport eller et stykke popularisering, eller journalist, måske med sidste nyt fra selve gerningsste-. det, for ikke at snakke om turisterne med deres souvenirs, postkort og lysbilleder. Grænserne mellem disse subgenrer er selvfølgelig blevet ved med at flyde, men mistænkeliggørelsen af den rejsende og øjet der ser, er siden slutningen af 1700 -tallet blevet sat i system som en mistænkeliggørelse 
af selve genren: kun det uddannede og trænede, det øvede og kvalificerede, det disciplinerede og autoriserede øje har siden kunne anses for at være i stand til at se det som før enhver kunne se der havde været på stedet. I gamle dage kunne man blive berømt for bare at have været andre steder, siden begyndelsen af det 19. århundrede skulle man i stigende grad være kendt på forhånd som forfatter, som forsker eller måske som journalist for at ens rejseberetning i det hele taget blev lagt mærke til.

I forskningens og den akademiske verden har rejsebeskrivelser altid været behandlet som stedbørn: skrevet af andre kunne de bruges som kilder og analyseres som kunstværker eller litteratur. Men det krævede en god undskyldning, hvis forskerne selv skulle benytte sig af genren for at fremlægge eller popularisere deres forskningsresultater. På een undtagelse nær, nemlig den etnografiske monografi sådan som den er blevet kanoniseret $\mathrm{i}$ begyndelsen af det 20. århundrede. På basis af feltarbejdet og deltagerobservationen som metode medførte helt af sig selv, at antropologiske forskningsresultater i allerhøjeste tog form af hvad vi kunne kalde en videnskabelig rejseberetning: rejseforløbet står der næsten ikke noget om, men tekstens videnskabelige autoritet hviler til gengæld helt og holdent på, at forfatteren selv har været derude og se.

Det er efter min bedste overbevisning ikke nogen tilfældighed, at den etnografiske monografi, der sædvanligvis regnes for at have indstiftet genren, nemlig Bronislaw Malinowskis Argonauts of the Western Pacific fra 1921, i så høj grad havde de indfødtes egne rejser som tema. Analysen af Kularingen, udvekslingen af rituelle og økonomiske værdigenstande mellem en lang række forskellige øer, var også et eftertrykkeligt fingerpeg om, at "de primitive" kunne være ganske som os andre i hver fald i den ene henseende, at de også selv - som antikkens argonauter - begav sig på langstrakte rejser.

Hvilket fører mig til mit egentlige anliggende: at der nemlig ved siden af den traditionelle (eller antikvariske), den eksemplariske (eller monumentale), den kritiske og den historisk-videnskabelige omgang med gamle rejseberetninger også findes en femte måde at beskxftige sig med rejsebeskrivelser på, som vi for nemheds skyld kunne kalde den mentalitetshistoriske. Man kan jo nemlig også se bort fra om det de rejsende skrev nu også er rigtigt, efterlignelsesværdigt, eller kritisabelt, og i stedet for at forstå fra deres beskrivelser ud fra deres samtids historiske kontekst, tage dem på ordet som 

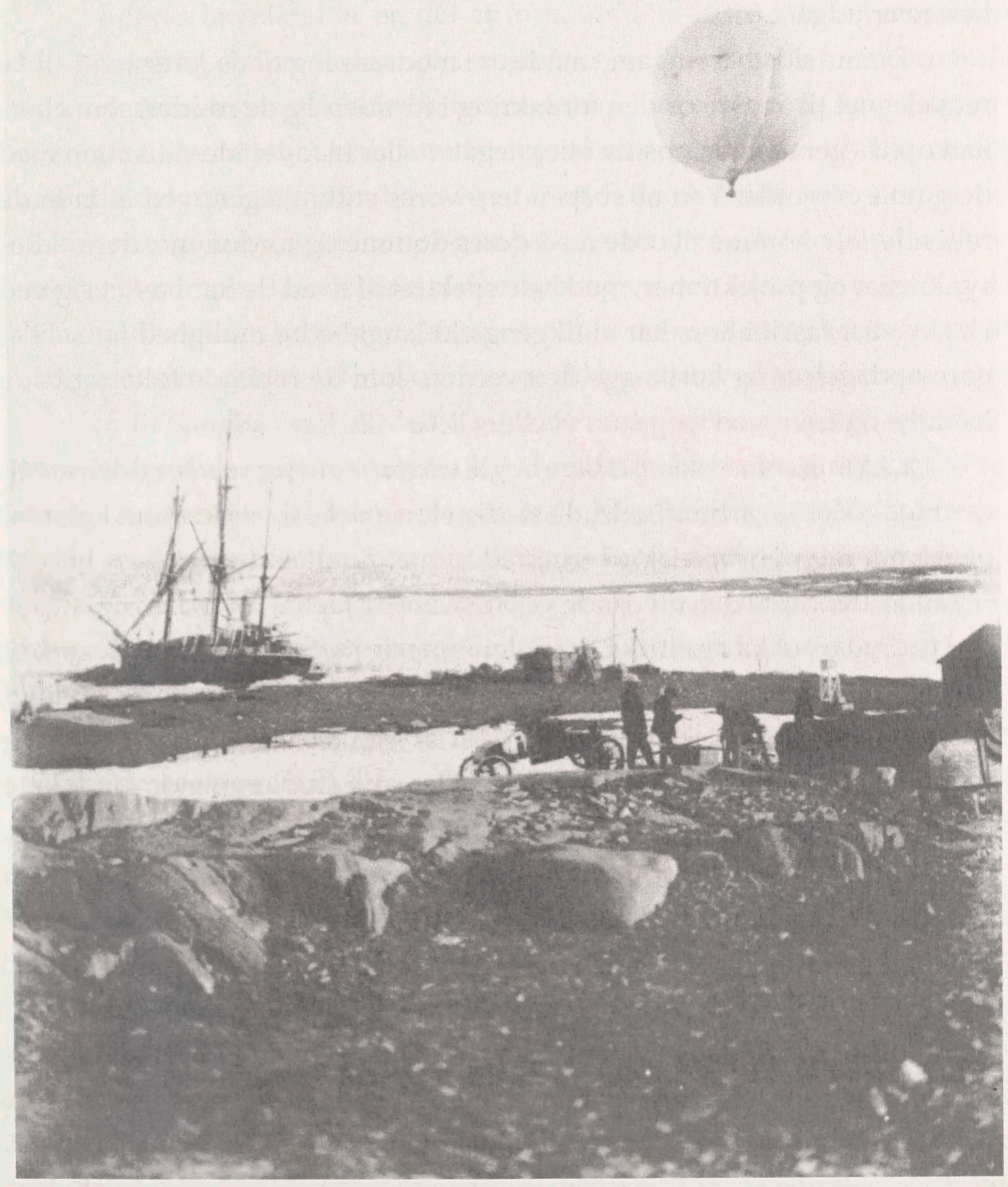

Ballonopstigning i Danmarkshavn 1907. Danmark-ekspeditionen 1906-1908 havde til formål at udforske Nordøstgrønland. Ekspeditionen kostede Jørgen Brønlund, Høeg Hagen og Mylius Erichsen livet. Foto: Arktisk Institut. 
sandhedsvidner om hvordan de selv og deres samtidige læsere opfattede deres egen såvel som andre verdener og hvordan disse opfattelser har ændret sig gennem tiden. Man kan jo nemlig også - som en slags historisk antropolog - behandle rejsende fra gamle dage som informanter: som særligt velinformerede indfødte, der netop fordi de har været viden om i verden kan fortælle os så meget des mere om den verden, de selv og deres samtidige læsere er udgået fra.

Denne sidste fremgangsmåde er i modsætning til de foregående ikke ret velegnet til at give os den forankring i fortiden og de rødder, som ellers kan opnås gennem en positiv eller negativ eller blandet identifikation med de gamle rejsende. Ved at suspendere vores stillingtagen, ved at lade de rejsende selv komme til orde med deres domme og fordomme, deres idiosynkrasier og projektioner, med hele spektret af hvad de har hæftet sig ved i afsky eller fascination, har vi til gengæld langt bedre mulighed for selv at gøre opdagelser og kortlægge den verden, som de rejsende følte sig både hjemme og fremmed i, og som vi ellers ikke ville have adgang til.

Lad mig som eksempel tage nogle tekster, som jeg selv for tiden arbejder med. I det 19. århundrede, da stadig større dele af verden som kolonier blev underlagt europæisk overherredømme, fandtes der også en hel del rejsende, der rejste den modsatte vej: fra Kina og Japan, fra Indien og Ægypten, fra Sydamerika og Afrika, fra kolonierne og perferien med andre ord, til verdens centrum. De fleste af disse rejsende tog mere eller mindre frivilligt på vej som diplomatiske udsendinge for at føre forhandlinger og lade sig presse til at indgå ufordelagtige aftaler eller som studierejsende for at lære om statskunst og hærvæsen, om landbrug og brobyggeri, om filosofi og historie. Andre blev taget med af missionærer og opdagelsesrejsende som informanter for lærde linguister eller for at blive vist frem i kirkelige forsamlinger som nyligt omvendte hedninge eller udstillet som ægte "vilde" eller "orientalere" på kongresser, verdensudstillinger og i zoologiske haver.

Der er selvfølgelig blevet skrevet en hel del om disse eksotiske gæster i den europæiske offentlighed. Men en del af disse rejsende har også selv ført dagbog eller endda fået udgivet en rejseberetning efter hjemkomsten og det er disse beskrivelser af Europa og europæerne som et "anderledes" sted og folkefærd jeg for tiden er ved at fordybe mig i.

Hvis jeg var ude efter et sandt og dækkende billede af Europa og 
europæerne i det 19. århundrede, ville jeg givetvis kunne have større glæde af alle mulige andre typer af kilder skrevet af europæiske forfattere med langt større indsigt i europæiske forhold og begivenheder. Hvis man til gengæld er interesseret mindre i hvordan der var i virkeligheden, men snarere i hvordan det var at være i Europa som udefra kommende gæst, findes der næppe mere oplagte kilder.

I deres hjemland er en del af forfatterne til disse kilder i eftertiden blevet fejret og dyrket som sande foregangsmænd: som helte for reformerne og moderniseringen af landet og bannerførere for en dengang kun spagfærdigt spirende nationalisme. Mindst lige så ofte er de blevet kritiseret for nøjagtig det modsatte: nemlig at have forrådt deres sande ophav og oprindelse ved at gå kolonialherrenes og imperialismens ærinde ved blindt at have overtaget europæernes billede af dem selv og verden i det hele taget. Og de få moderne videnskabelige analyser består som regel blot i forsøget på at afveje disse modstridende tolkninger mod hinanden ved at vurderere deres relative fortjenester ud fra deres samtids muligheder og forudsætninger. Men heller ikke i disse analyser har de udefra kommende iagttagere ret mange chancer for at komme til orde med deres beskrivelser af det Europa og de europæere, som enhver historiker jo kender langt bedre gennem alskens andre kilder. Hvis man derimod tager sig den mentalitetshistoriske og historisk-antropologiske frihed for en stund at se bort fra hvordan det var "i virkeligheden", ville man i det mindste ikke forhånd have afskåret sig fra at erkende, hvordan virkeligheden har taget sig ud i disse informanters (og måske deres læseres) øjne.

Montesquieu har som bekendt haft en uvurderlig betydning for samfundstænkningen siden det 18. århundrede. Måske er der også noget at lære af de mange Perserbreve, der i det 19. århundrede blev skrevet af mere obskure forfattere af mere eksotisk herkomst.

Det kongelige Biblioteks samlinger rummer en aldeles uoverskuelig bestand af rejseberetninger, og der er næppe grænser for de svar de kan give både om virkeligheden og om hvordan den er blevet opfattet af både os selv og vores forfædre og alle mulige andre. Det er med rejseberetninger ligesom med det frie, kapitalistiske marked: de fortæller begge en masse om produktionen og virkeligheden, men aldrig uden samtidig at tale om efterspørgslen og opfattelserne af denne virkelighed. De fremstår begge altid som 
uregerlig og anarkistisk, befriende og antiautoritær, de er begge grænseoverskridende i mere end een betydning af ordet. Når det gælder markedet, er der i vore dage ikke ret mange, der tvivler på dens velsignelser. Når det gælder rejsebeskrivelser, nærer jeg selv en lignende tillid. Hvis jeg skal være helt ærlig, har jeg faktisk en gang imellem - ligesom Immanuel Kant - svært ved at forstå hvorfor i alverden Det kongelige Bibliotek har anskaffet så meget andet!

1 Historien er gengivet af Walter Benjamin under titlen Eine Geschichte, in der Kant sich kurz faßt. (Gesammelte Schriften vol. IV, 2: 809). Jeg er blevet gjort opmærksom på den af Thomas Bremers artikel Il viaggio sulla carta. Viaggi come strategia di dis- corso in Kant. I: M. Enrica D'Agostini (red.), La letteratura di viaggio. Storia e prospettive di un genere letterario. Milano 1987. Tak iøvrigt tilStatens Humanistiske Forskningsråd for utrættelig støtte til min rejseforskning. 